\title{
Pharmacokinetics of aprepitant and dexamethasone after administration of chemotherapeutic agents and effects of plasma substance $P$ concentration on chemotherapy-induced nausea and vomiting in Japanese cancer patients
}

\author{
Toshiaki Takahashi $\cdot$ Yukiko Nakamura $\cdot$ \\ Asuka Tsuya $\cdot$ Haruyasu Murakami · \\ Masahiro Endo $\cdot$ Nobuyuki Yamamoto
}

Received: 21 July 2010/ Accepted: 1 November 2010/Published online: 2 December 2010

(C) The Author(s) 2010. This article is published with open access at Springerlink.com

\begin{abstract}
Purpose This study was conducted to determine the pharmacokinetics of aprepitant and dexamethasone as well as the relationship between the plasma concentration of substance $\mathrm{P}$ and nausea/vomiting in Japanese cancer patients.

Methods After administration of aprepitant (125/80 mg group [10 patients]: $125 \mathrm{mg}$ on day 1 and $80 \mathrm{mg}$ on days $2-5 ; 40 / 25 \mathrm{mg}$ group [10 patients]: $40 \mathrm{mg}$ on day 1 and $25 \mathrm{mg}$ on days 2-5) and dexamethasone (6 $\mathrm{mg}$ on day 1 and $4 \mathrm{mg}$ on days 2 and 3 in the $125 / 80 \mathrm{mg}$ group, and $8 \mathrm{mg}$ on day 1 and $6 \mathrm{mg}$ on days 2 and 3 in the 40/25 $\mathrm{mg}$ group) to Japanese cancer patients receiving at least moderately emetogenic antitumor agents, the plasma concentrations of aprepitant, dexamethasone, and substance $\mathrm{P}$ were measured.

Results All of 20 patients were treated with the highly emetogenic agent cisplatin $\left(\geq 70 \mathrm{mg} / \mathrm{m}^{2}\right)$. The $C_{\max }$ and $\mathrm{AUC}_{0-24 \mathrm{~h}}$ of aprepitant in Japanese cancer patients were similar with those in non-Japanese patients. The clearance of dexamethasone in the $125 / 80 \mathrm{mg}$ group was approximately one-half of that previously determined in the absence of aprepitant. The substance $\mathrm{P}$ concentration in
\end{abstract}

T. Takahashi ( $\varangle) \cdot$ Y. Nakamura · A. Tsuya $\cdot$ H. Murakami ·

N. Yamamoto

Division of Thoracic Oncology, Shizuoka Cancer Center,

1007 Shimonagakubo, Nagaizumi-cho, Sunto-gun,

Shizuoka 411-8777, Japan

e-mail: t.takahashi@scchr.jp

M. Endo

Division of Diagnostic Radiology, Shizuoka Cancer Center,

1007 Shimonagakubo, Nagaizumi-cho,

Sunto-gun, Shizuoka 411-8777, Japan plasma significantly increased only in patients with delayed nausea/vomiting.

Conclusions This study demonstrated similar plasma pharmacokinetics of aprepitant in Japanese and non-Japanese, the validity of reducing dexamethasone dose, and the existence of increased plasma substance $\mathrm{P}$ concentration in patients receiving highly emetogenic cisplatin-based chemotherapy.

Keywords Aprepitant - Dexamethasone - Substance P . Pharmacokinetics - Chemotherapy-induced nausea and vomiting

\section{Introduction}

Aprepitant is a neurokinin-1 $\left(\mathrm{NK}_{1}\right)$ receptor antagonist developed as a treatment for both acute and delayed chemotherapy-induced nausea and vomiting (CINV). It has a novel mechanism of action (i.e., by inhibiting the binding of substance $\mathrm{P}$ to the $\mathrm{NK}_{1}$ receptor in the vomiting center) [1-3]. In the guidelines for management of CINV, aprepitant is recommended to be used in combination with a serotonin antagonist and dexamethasone to prevent nausea/ vomiting induced by highly and moderately emetogenic cancer chemotherapy [4-6].

Although aprepitant has no effect on the pharmacokinetics of serotonin antagonists (ondansetron, granisetron, palonosetron) [7, 8], aprepitant inhibits CYP3A4 and in turn inhibits the metabolism of dexamethasone, a substrate of CYP3A4 [9]. It has been shown that the area under the concentration-time curve (AUC) of dexamethasone is increased approximately two times after administration of aprepitant at a dose of $125 \mathrm{mg}$ on day 1 and at a dose of $80 \mathrm{mg}$ on days $2-5$ in healthy adults, and so, to maintain 
dexamethasone at the prescribed blood level in the presence of aprepitant, the dose of dexamethasone has to be reduced by $50 \%$ [9]. Although a previous population pharmacokinetic study of dexamethasone combined with aprepitant supported the validity of this dose reduction of dexamethasone [10], there has been no full pharmacokinetic study of dexamethasone and aprepitant in cancer patients who receive emetogenic cancer chemotherapy.

While aprepitant may have an antiemetic effect by inhibiting the binding of substance $\mathrm{P}$ to the $\mathrm{NK}_{1}$ receptor in the vomiting center as mentioned above, it is still unclear whether there is any change in the in vivo kinetics of substance $\mathrm{P}$ after administration of chemotherapeutic agents, or how the in vivo kinetics of substance $\mathrm{P}$ is related to CINV.

This study was conducted to determine the pharmacokinetics of aprepitant as well as dexamethasone in Japanese cancer patients and to verify the dose reduction of dexamethasone used in combination with aprepitant, and furthermore, to evaluate the relationship between CINV and in vivo kinetics of substance $\mathrm{P}$ after administration of chemotherapeutic agents.

\section{Patients and methods}

\section{Inclusion criteria}

Japanese cancer patients aged between 20 and 74 years who received cancer chemotherapy were included in this study. Cancer chemotherapy consisted of at least moderately (Hesketh level $\geq 3$ [11]) emetogenic chemotherapeutic agents on day 1 only. With a performance status of $0-2$ and an estimated life expectancy of at least 3 months, patients met the following laboratory criteria: white blood cell count $\geq 3,000 / \mathrm{mm}^{3}$ and neutrophil count $\geq 1,500$ / $\mathrm{mm}^{3}$; platelet count $\geq 100,000 / \mathrm{mm}^{3}$; AST (GOT) and ALT (GPT) $\leq 1.5 \times$ upper limit of the normal range at the facility; ALP $\leq 2.5 \times$ upper limit of the normal range at the facility; total bilirubin $\leq 1.5 \mathrm{mg} / \mathrm{dL}$; and creatinine $\leq 1.5 \mathrm{mg} / \mathrm{dL}$. The following patients were excluded from the study: patients with a risk of vomiting for other reasons (symptomatic brain metastasis, meningeal infiltration, epilepsy, active peptic ulcer, gastrointestinal obstruction, concomitant abdominal or pelvic radiotherapy, etc.); and pregnant, nursing, or possibly pregnant women. After the protocol and informed consent form were approved by the institutional review board (IRB) at the facility, patients who gave written informed consent were enrolled. All studies were conducted in accordance with the principles of Good Clinical Practice (GCP) and the basic principles of the Declaration of Helsinki.
Design and treatment

This was an open-label study. A total of 20 patients were randomized to receive aprepitant at an oral dose of 125/ $80 \mathrm{mg}$ ( $125 \mathrm{mg}$ on day 1 and $80 \mathrm{mg}$ on days $2-5 ; n=10$ ) or $40 / 25 \mathrm{mg}$ ( $40 \mathrm{mg}$ on day 1 and $25 \mathrm{mg}$ on days $2-5$; $n=10$ ). In addition, all patients received standard antiemetic therapy consisting of intravenous granisetron $(40 \mu \mathrm{g} /$ $\mathrm{kg}$ on day 1) and intravenous dexamethasone sodium phosphate (on days 1-3). In this study, the dose of intravenous dexamethasone was $6 \mathrm{mg}$ on day 1 and $4 \mathrm{mg}$ on days 2 and 3 in the 125/80-mg group and $8 \mathrm{mg}$ on day 1 and $6 \mathrm{mg}$ on days 2 and 3 in the $40 / 25 \mathrm{mg}$ group. Although, in the antiemetic guidelines [4-6], it is recommended that dexamethasone is administered at a dose of $12 \mathrm{mg}$ on day 1 and at a dose of $8 \mathrm{mg}$ on day 2 and thereafter in combination with aprepitant $125 / 80 \mathrm{mg}$, the dose of dexamethasone in this study was determined in order to compare the clearance of dexamethasone in this study with that obtained from Japanese cancer patients in the absence of aprepitant at a dose of $12 \mathrm{mg}$ dexamethasone on day 1 [10].

\section{Pharmacokinetic evaluation}

Blood samples for measurement of plasma aprepitant concentration were collected before administration of aprepitant on days $1-5$ and 1, 2, 3, 5, 9, 11, and $24 \mathrm{~h}$ after administration of aprepitant on day 1 and on day 5 only. In addition, a separate set of blood samples for measurement of plasma dexamethasone concentration were collected immediately, $15 \mathrm{~min}, 30 \mathrm{~min}$, and $1.5,3.5,7.5,9.5$, and $22.5 \mathrm{~h}$ after administration of dexamethasone on day 1 .

Methods for measurement of plasma aprepitant and dexamethasone concentrations

For each subject, venous blood was collected in an EDTA 2Na-treated tube at each sampling time point and immediately centrifuged at approximately $1,500 \mathrm{~g}$ (approximately 3,000 rpm) for $10 \mathrm{~min}$ at room temperature. Then, the resultant plasma was transferred to a polypropylene tube and stored frozen at $-20^{\circ} \mathrm{C}$. The plasma concentrations of aprepitant and dexamethasone were measured by liquid chromatography/tandem mass spectrometry (LC/ MS/MS). After methanol was added to plasma, the internal standard and carbonate buffer (for aprepitant) or ammonium acetate buffer (for dexamethasone) were added and mixed. Then, $t$-butyl methyl ether (for aprepitant) or diethyl ether (for dexamethasone) was added to and mixed with the plasma sample and centrifuged. After the aqueous layer was frozen in a methanol/dry ice bath, the entire organic layer was collected in a tube and placed under 
nitrogen stream at approximately $40^{\circ} \mathrm{C}$ to remove the solvent. The residue was suspended in ammonium acetate aqueous solution (containing formic acid)/acetonitrile (for aprepitant) or methanol/water (for dexamethasone) for use in $\mathrm{LC} / \mathrm{MS} / \mathrm{MS}$.

The pharmacokinetic parameters of aprepitant and dexamethasone were calculated by non-compartment analysis using WinNonlin Professional ${ }^{\circledR}$ software Ver.4.0.1 (Pharsight Corporation, Mountain View, CA, USA). The maximum plasma concentration $\left(\mathrm{C}_{\max }\right)$, time to maximum plasma concentration $\left(\mathrm{t}_{\max }\right)$, and area under the plasma concentration-time curve from 0 to $24 \mathrm{~h}$ post-dose $\left(\mathrm{AUC}_{0-24 \mathrm{~h}}\right.$ ) were calculated for aprepitant, and the $\mathrm{C}_{\max }$, area under the plasma concentration-time curve from 0 to infinity $\left(\mathrm{AUC}_{0-\infty}\right), \mathrm{t}_{1 / 2}$, total clearance $\left(\mathrm{CL}_{\mathrm{tot}}\right)$, and volume of distribution at steady state $\left(\mathrm{V}_{\mathrm{ss}}\right)$ were calculated for dexamethasone.

\section{Assessment of substance P}

Before administration of aprepitant on days 1-5, venous blood was collected in an ethylenediaminetetraacetic acid (EDTA)/aprotinin-treated tube from each subject and inverted to mix. After blood was immediately centrifuged at $1,500 \mathrm{~g}$ (approximately 3,000 rpm) for $10 \mathrm{~min}$ at $4^{\circ} \mathrm{C}$, $0.5 \mathrm{~mL}$ of plasma was stored frozen at $-20^{\circ} \mathrm{C}$. The plasma substance $\mathrm{P}$ concentration was measured by enzyme immunoassay (EIA).

\section{Statistical analysis}

To assess ethnic differences in the pharmacokinetics of aprepitant, the $\mathrm{C}_{\max }$ and $\mathrm{AUC}_{0-24 \mathrm{~h}}$ at a dose of $125 \mathrm{mg}$ in Japanese cancer patients were compared with those in nonJapanese cancer patients [12] by calculating the geometric mean ratio (Japanese/non-Japanese) and its 90\% confidence interval for each parameter.

To assess the validity of adjusting the dose of dexamethasone in the $125 / 80$ and $40 / 25 \mathrm{mg}$ groups, the exposure levels of dexamethasone were compared. The $\mathrm{C}_{\max }$ and $\mathrm{AUC}_{0-\infty}$ of dexamethasone in each group were used to calculate the geometric mean ratio (125/80 mg group/40/ $25 \mathrm{mg}$ group) and its $90 \%$ confidence interval for each parameter. In addition, the clearance of dexamethasone in each group was compared with that calculated in the absence of aprepitant in Japanese cancer patients [10].

For substance $\mathrm{P}$, the plasma concentration on each measurement day was used to assess the change on day 2 and thereafter, and these changes were evaluated by paired $t$ test.

This study was designed and funded by Ono pharmaceutical Co., Ltd. and Merck \& Co., Inc., the manufacturer of aprepitant.

\section{Results}

Patients

A total of 20 patients (10 in the $125 / 80 \mathrm{mg}$ group and 10 in the $40 / 25 \mathrm{mg}$ group) were included. Patients' characteristics are shown in Table 1 . There were 18,1 , and 1 patients with non-small cell lung cancer, small-cell lung cancer, and mesothelioma, respectively. All were treated with at least the highly emetogenic chemotherapeutic agent cisplatin $\left(\geq 70 \mathrm{mg} / \mathrm{m}^{2}\right)$. The two groups were generally similar in age, sex, height, and body weight.

Pharmacokinetics of aprepitant

All 20 enrolled patients were included in the pharmacokinetic analysis. The pharmacokinetic parameters of aprepitant are shown in Table 2 . In the $125 / 80 \mathrm{mg}$ group, the $\mathrm{AUC}_{0-24 \mathrm{~h}}$ on days 1 and 5 increased out of proportion to the dose, compared with that in the $40 / 25 \mathrm{mg}$ group.

The geometric mean ratio and its $90 \%$ confidence interval $(\mathrm{CI})$ of the $\mathrm{C}_{\max }$ and $\mathrm{AUC}_{0-24 \mathrm{~h}}$ of aprepitant in Japanese cancer patients to non-Japanese cancer patients was 1.09 (0.79-1.52) and $1.12(0.87-1.45)$, respectively,

Table 1 Characteristics of patients

\begin{tabular}{lll}
\hline Characteristics & $\begin{array}{l}125 / 80 \mathrm{mg} \\
\text { regimen } \\
n=10\end{array}$ & $\begin{array}{l}40 / 25 \mathrm{mg} \\
\text { regimen } \\
n=10\end{array}$ \\
\hline $\begin{array}{l}\text { Male/female }(N) \\
\text { Age (years) }\end{array}$ & $6 / 4$ & $7 / 3$ \\
Mean (S.D.) & $59.7(6.7)$ & $63.6(5.9)$ \\
Range & $47-71$ & $55-72$ \\
Height (cm) & & \\
Mean (S.D.) & $161.16(9.91)$ & $161.24(12.97)$ \\
Range & $147.0-179.5$ & $139.2-177.3$ \\
Weight (kg) & & \\
Mean (S.D.) & $55.72(10.28)$ & $56.86(14.17)$ \\
Range & $42.2-76.6$ & $42.4-82.7$ \\
Primary cancer diagnosis $(N)$ & & 9 \\
Non-small cell lung cancer & 9 & 0 \\
Small-cell lung cancer & 1 & 1 \\
Mesothelioma & 0 & 5 \\
Chemotherapy regimen $(N)$ & & 2 \\
Cisplatin + gemcitabine & 3 & 0 \\
Cisplatin + tegafur/gimeracil/ & 2 & \\
$\quad$ oteracil & 2 & \\
Cisplatin + vinorelbine & 2 & \\
Cisplatin + etoposide & 1 & \\
Cisplatin + docetaxel & & \\
\hline
\end{tabular}


Table 2 Summary of the pharmacokinetics of aprepitant on days 1 and 5

\begin{tabular}{llll}
\hline Day & Parameter & $\begin{array}{l}125 / 80 \mathrm{mg} \\
\text { regimen }\end{array}$ & $\begin{array}{l}40 / 25 \mathrm{mg} \\
\text { regimen }\end{array}$ \\
\hline 1 & $\mathrm{C}_{\max }(\mathrm{ng} / \mathrm{mL})$ & $2,210 \pm 870$ & $536 \pm 105$ \\
& $\mathrm{~T}_{\max }(\mathrm{h})$ & $7.0(3.0-9.0)$ & $3.0(2.0-9.0)$ \\
& $\mathrm{AUC}_{0-24 \mathrm{~h}}(\mathrm{ngh} / \mathrm{mL})$ & $30,000 \pm 8,700$ & $6,360 \pm 1,350$ \\
5 & $\mathrm{C}_{\max }(\mathrm{ng} / \mathrm{mL})$ & $3,070 \pm 850$ & $453 \pm 109$ \\
& $\mathrm{~T}_{\max }(\mathrm{h})$ & $3.0(2.0-9.0)$ & $3.0(2.0-3.0)$ \\
& $\mathrm{AUC}_{0-24 \mathrm{~h}}(\mathrm{ngh} / \mathrm{mL})$ & $46,000 \pm 17,100$ & $5,420 \pm 1,680$ \\
\hline
\end{tabular}

Mean $\pm \mathrm{SD}, \mathrm{T}_{\max }$ median (range)

$C_{\max }$, maximum plasma concentration, $T_{\max }$, time to maximum plasma concentration, $A U C_{0-24 \mathrm{~h}}$ area under plasma concentrationtime curve from 0 to $24 \mathrm{~h}$ post-dose

showing little differences between Japanese and nonJapanese groups in the pharmacokinetics of aprepitant.

Pharmacokinetics of dexamethasone

For dexamethasone, the pharmacokinetic parameters and time profile of plasma concentration on day 1 in the 125/80 and 40/25 mg groups are shown in Table 3 and Fig. 1, respectively. The geometric mean ratio $(90 \% \mathrm{CI})$ of $\mathrm{C}_{\max }$ and $\mathrm{AUC}_{0-\infty}$ of dexamethasone on day 1 in the $125 / 80 \mathrm{mg}$ group to the 40/25 mg group was $0.83(0.73-0.94)$ and 1.15 (0.88-1.50), respectively, showing that although the $\mathrm{C}_{\max }$ tended to be high in the $40 / 25 \mathrm{mg}$ group, the $\mathrm{AUC}_{0-\infty}$ was similar between the two treatment groups. To verify the dose reduction of dexamethasone in cancer patients who receive emetogenic cancer chemotherapy in combination with aprepitant, we compared the clearances of dexamethasone in this study with that obtained from Japanese

Table 3 Pharmacokinetic parameters of dexamethasone in each treatment group (on day 1)

\begin{tabular}{lcc}
\hline Parameter & $\begin{array}{l}125 / 80 \mathrm{mg} \text { regimen } \\
\text { (Dexamethasone } \\
6 \mathrm{mg})\end{array}$ & $\begin{array}{l}40 / 25 \mathrm{mg} \text { regimen } \\
\text { (Dexamethasone } \\
8 \mathrm{mg})\end{array}$ \\
\hline $\mathrm{C}_{\text {max }}(\mathrm{ng} / \mathrm{mL})$ & $121 \pm 17$ & $147 \pm 27$ \\
$\mathrm{AUC}_{0-\mathrm{t}}(\mathrm{ngh} / \mathrm{mL})$ & $823 \pm 213$ & $838 \pm 253$ \\
$\mathrm{AUC}_{0-\infty}(\mathrm{ngh} / \mathrm{mL})$ & $1,020 \pm 300$ & $899 \pm 287$ \\
$\mathrm{t}_{1 / 2}(\mathrm{~h})$ & $9.6 \pm 2.4$ & $5.7 \pm 1.4$ \\
$\mathrm{CL}_{\text {tot }}(\mathrm{L} / \mathrm{h})$ & $6.48 \pm 2.50$ & $10.0 \pm 4.1$ \\
$\mathrm{~V}_{\mathrm{ss}}(\mathrm{L})$ & $74.6 \pm 14.3$ & $65.5 \pm 11.7$ \\
\hline
\end{tabular}

Mean \pm SD

$C_{\max }$ maximum plasma concentration, $A U C_{0-t}$, area under plasma concentration-time curve from 0 to the last measurable concentration, $A U C_{0-\infty}$, area under plasma concentration-time curve from 0 to infinity, $t_{1 / 2}$ elimination half-life, $C L_{t o t}$ total clearance, $V_{s s}$ volume of distribution at steady state

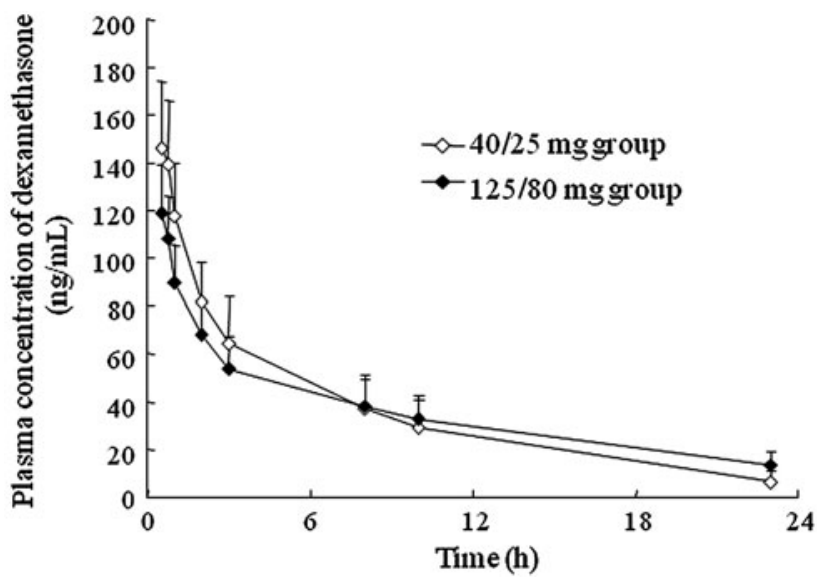

Fig. 1 Time profile of plasma dexamethasone concentration in each treatment group (day 1). Mean $+\mathrm{SD}(n=10)$

cancer patients in the absence of aprepitant at a dose of $12 \mathrm{mg}$ on day $1(13.3 \mathrm{~L} / \mathrm{h})$ [10]. In the $125 / 80$ and $40 /$ $25 \mathrm{mg}$ groups (dexamethasone at a dose of 6 and $8 \mathrm{mg}$ on day 1 , respectively), the clearance of dexamethasone was 6.48 and $10.0 \mathrm{~L} / \mathrm{h}$, respectively. That is, the clearances of dexamethasone in the $125 / 80$ and $40 / 25 \mathrm{mg}$ groups decrease by approximately 52 and $25 \%$, respectively. These results demonstrate the validity of reducing the dose of dexamethasone by 50 and $25 \%$ in the $125 / 80$ and $40 /$ $25 \mathrm{mg}$ groups, compared with the dose of dexamethasone in the absence of aprepitant.

\section{Evaluation of plasma substance $\mathrm{P}$}

The time profile of plasma substance $\mathrm{P}$ concentration after administration of chemotherapeutic agents in all 20 patients (days 1-5) is shown in Fig. 2. The substance $P$

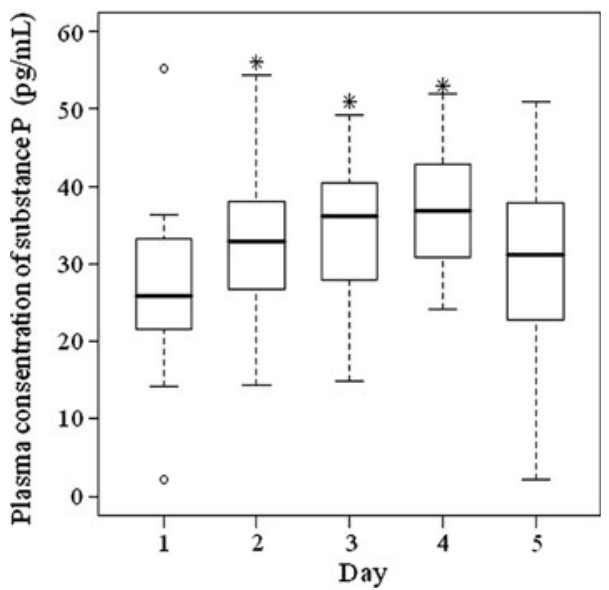

Fig. 2 Time profile of plasma substance $\mathrm{P}$ concentration $(n=20)$. Top bar highest value in the range of quartile $\times 1.5$; lower bar lowest value in the range of quartile $\times 1.5$; top of box upper quartile; bottom of box lower quartile; middle bar: median value; circles outliers $* P<0.05$ compared with baseline (day 1 ) concentration 
Fig. 3 Change in plasma substance $\mathrm{P}$ concentration $(n=19)$. Top bar highest value in the range of quartile $\times 1.5$; lower bar lowest value in the range of quartile $\times 1.5$; top of box upper quartile; bottom of box lower quartile; middle bar median value; circles outliers ${ }^{*} P<0.05$ between days 2 and 5 compared with baseline (day 1 )
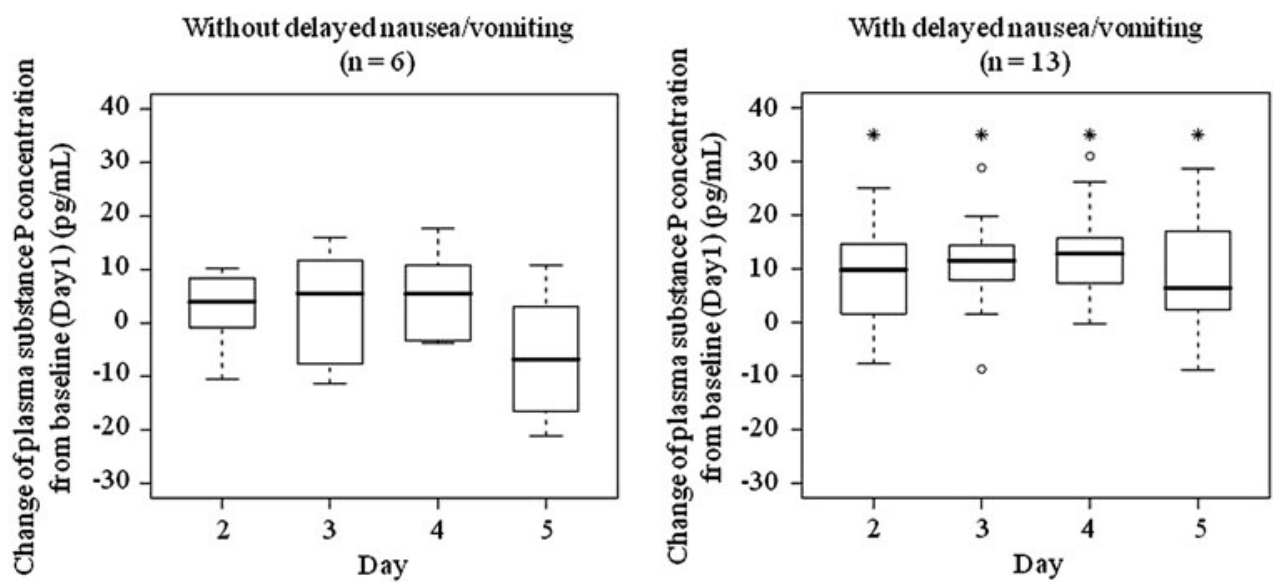

concentration significantly increased on days 2-4, compared with that on day 1 (baseline) $(P<0.05$, paired $t$ test).

There was no difference in the change in the plasma substance $\mathrm{P}$ concentration between the 125/80 and 40/ $25 \mathrm{mg}$ groups (data not shown). The change in substance $\mathrm{P}$ concentration in plasma from baseline (the concentration before the start of treatment with aprepitant) in patients with or without delayed nausea/vomiting is shown in Fig. 3. One patient had missing data for the substance $P$ concentration on day 1 , and so we analyzed the change in substance $\mathrm{P}$ concentration from baseline (day 1) in 19 patients. In patients with delayed nausea/vomiting, substance $\mathrm{P}$ concentration increased significantly between days 2 and 5 compared with baseline (day 1$)(P<0.05$, paired $t$ test). On the other hand, in patients without delayed nausea/vomiting, the increase in substance $\mathrm{P}$ concentration on days 2-5 was not statistically significant.

\section{Discussion}

In this study, the pharmacokinetics of aprepitant and dexamethasone were determined in Japanese cancer patients receiving emetogenic chemotherapeutic agents. There were no differences in the pharmacokinetics of aprepitant between Japanese and non-Japanese cancer patients. In addition, we showed the validity of dose adjustment of dexamethasone used in combination with aprepitant (i.e., reducing the dose of dexamethasone by $50 \%$ when combined with $125 \mathrm{mg}$ of aprepitant). We also found that the blood concentration of substance $\mathrm{P}$, which is deeply involved in the pharmacological effects of aprepitant, increased after administration of chemotherapeutic agents.

In the present study, the geometric mean ratio of the $\mathrm{C}_{\max }$ and $\mathrm{AUC}_{0-24 \mathrm{~h}}$ in Japanese cancer patients to nonJapanese cancer patients was 1.09 and 1.12, respectively, indicating no ethnic differences in the pharmacokinetics of aprepitant. In the aprepitant $125 / 80 \mathrm{mg}$ group, more than dose-proportional increase in $\mathrm{AUC}_{0-24 \mathrm{~h}}$ occurred on both days 1 and 5, compared with that in the 40/25 $\mathrm{mg}$ group. Aprepitant is primarily metabolized by CYP3A4 [13], and this more than proportional increase in the $\mathrm{AUC}_{0-24 \mathrm{~h}}$ of aprepitant may reflect saturated metabolism of aprepitant via CYP3A4 as previously reported in healthy non-Japanese volunteers [14].

In this study, granisetron hydrochloride and dexamethasone sodium phosphate were concomitantly used as standard antiemetic therapy. Aprepitant-dexamethasone interaction causes the increase in plasma dexamethasone concentration [9], and it has been suggested that this drug interaction may also cause a slight increase in the incidence of infection-related serious adverse events [15]. Since the AUC of dexamethasone (p.o.) has been shown to increase approximately two times after administration of aprepitant at a dose of $125 \mathrm{mg}$ on day 1 in healthy adults [9], the dose of dexamethasone has to be reduced by $50 \%$ when used in combination with $125 \mathrm{mg}$ of aprepitant. While oral dexamethasone was used in the report by McCrea et al. [9], this was the first full pharmacokinetic study of intravenous administration of dexamethasone when used in combination with aprepitant in cancer patients actually receiving chemotherapeutic agents. In the $125 / 80 \mathrm{mg}$ group, the clearance of intravenous dexamethasone decreased by approximately $52 \%$ from that calculated in the absence of aprepitant, justifying a $50 \%$ dose reduction of intravenous dexamethasone used in combination with $125 \mathrm{mg}$ of aprepitant in cancer patients as McCrea et al. demonstrated in healthy adults [9]. And the results from this full pharmacokinetic study also supported a report using a population pharmacokinetics model by Nakade et al. [10] that the clearance of intravenous dexamethasone used in combination with aprepitant at a dose of $125 \mathrm{mg}$ decreased by $47.5 \%$ of that in the absence of aprepitant.

While aprepitant may exert its antiemetic effect during chemotherapy, by inhibiting the binding of substance $\mathrm{P}$ to 
the $\mathrm{NK}_{1}$ receptor in the vomiting center [1], few studies have been conducted to investigate the relationship between the blood pharmacokinetics of substance $\mathrm{P}$ and nausea/vomiting during treatment with chemotherapeutic agents in humans. Substance P has been shown to be colocalized with serotonin in enterochromaffin cells in the gastrointestinal tract [16] and cross the blood-brain barrier in animals [17]. These reports raise the possibility that substance $\mathrm{P}$ of peripheral origin may act centrally to induce emesis. However, it is still not shown whether exocytotic release of substance $\mathrm{P}$ from enterochromaffin cells in the gastrointestinal tract occurs after administration of emetogenic agents. This study showed that the plasma substance $\mathrm{P}$ concentration significantly increased on days $2-4$ after administration of chemotherapeutic agents. It was also shown that the plasma substance P concentration significantly increased only in patients with delayed nausea/ vomiting. These results, as well as the report from Higa [18], support the possibility that the elevation of the plasma substance $\mathrm{P}$ concentration by emetogenic chemotherapeutic agents may be involved in the pathogenesis of CINV, especially in the delayed phase. The plasma substance $\mathrm{P}$ concentration ranged from 0 to $1,608 \mathrm{pg} / \mathrm{mL}$ in a report by Higa et al. [18] and from $2-55 \mathrm{pg} / \mathrm{mL}$ in the present study. The cause of this difference is unknown, but may be attributed to different assay kits used to measure the substance $\mathrm{P}$ concentration (Higa et al. used R\&D systems, and we used Cayman Chemical).

In conclusion, this study demonstrated similar plasma pharmacokinetics of aprepitant in Japanese and non-Japanese, the validity of reducing dexamethasone dose, and the existence of increased substance $P$ concentration in patients receiving highly emetogenic cancer chemotherapy. Further studies are required to clarify whether measurement of the plasma pharmacokinetics of substance $\mathrm{P}$ may be a clinically meaningful marker for CINV in patients receiving emetogenic agents.

\section{Conflict of interest None.}

Open Access This article is distributed under the terms of the Creative Commons Attribution Noncommercial License which permits any noncommercial use, distribution, and reproduction in any medium, provided the original author(s) and source are credited.

\section{References}

1. Tattersall FD, Rycroft W, Cumberbatch M, Mason G, Tye S, Williamson DJ, Hale JJ, Mills SG, Finke PE, MacCoss M, Sadowski S, Ber E, Cascieri M, Hill RG, MacIntyre DE, Hargreaves RJ (2000) The novel NK1 receptor antagonist MK-0869 (L-754, 030) and its water soluble phosphoryl prodrug, L-758, 298, inhibit acute and delayed cisplatin-induced emesis in ferrets. Neuropharmacology 39:652-663

2. Warr DG, Grunberg SM, Gralla RJ, Hesketh PJ, Roila F, Wit R, Carides AD, Taylor A, Evans JK, Horgan KJ (2005) The oral $\mathrm{NK}_{1}$ antagonist aprepitant for the prevention of acute and delayed chemotherapy-induced nausea and vomiting: pooled data from 2 randomised, double-blind, placebo controlled trials. Eur J Cancer 41:1278-1285

3. Warr DG, Hesketh PJ, Gralla RJ, Muss HB, Herrstedt J, Eisenberg PD, Raftopoulos H, Grunberg SM, Gabriel M, Rodgers A, Bohidar N, Klinger G, Hustad CM, Horgan KJ, Skobieranda F (2005) Efficacy and tolerability of aprepitant for the prevention of chemotherapy-induced nausea and vomiting in patients with breast cancer after moderately emetogenic chemotherapy. J Clin Oncol 23:2822-2830

4. Kris MG, Hesketh PJ, Somerfield MR, Feyer P, Clark-Snow R, Koeller JM, Morrow GR, Chinnery LW, Chesney MJ, Gralla RJ, Grunberg SM (2006) American society of clinical oncology guideline for antiemetics in oncology: update 2006. J Clin Oncol 24:2932-2947

5. Rolia F, Hesketh PJ, Herrstedt J (2006) The Antiemetic Subcommittee of the Multinational Association of Supportive Care in Cancer (MASCC). Prevention of chemotherapy- and radiotherapy-induced emesis: results of the 2004 Perugia international antiemetic consensus conference. Ann Oncol 17:20-28

6. NCCN Clinical practice guidelines in oncology ${ }^{\mathrm{TM}}$ (2007) Antiemesis V.1

7. Blum RA, Majumdar A, McCrea J, Busillo J, Orlowski LH, Panebianco D, Hesney M, Petty KJ, Goldberg MR, Murphy MG, Gottesdiener KM, Hustad CM, Lates C, Kraft WK, Van Buren S, Waldman SA, Greenberg HE (2003) Effects of aprepitant on the pharmacokinetics of ondansetron and granisetron in healthy subjects. Clin Ther 25:1407-1419

8. Shah AK, Hunt TL, Gallagher SC, Cullen MT Jr (2005) Pharmacokinetics of palonosetron in combination with aprepitant in healthy volunteers. Curr Med Res Opin 21:595-601

9. McCrea JB, Majumdar AK, Goldberg MR, Iwamoto M, Gargano C, Panebianco DL, Hesney M, Lines CR, Petty KJ, Deutsch PJ, Murphy MG, Gottesdiener KM, Goldwater DR, Blum RA (2003) Effects of the neurokinin ${ }_{1}$ receptor antagonist aprepitant on the pharmacokinetics of dexamethasone and methylprednisolone. Clin Pharmacol Ther 74:17-24

10. Nakade S, Ohno T, Kitagawa J, Hashimoto Y, Katayama M, Awata H, Kodama Y, Miyata Y (2008) Population pharmacokinetics of aprepitant and dexamethasone in the prevention of chemotherapy-induced nausea and vomiting. Cancer Chemother Pharmacol 63:75-83

11. Hesketh PJ, Kris MG, Grunberg SM, Beck T, Hainsworth JD, Harker G, Aapro MS, Gandara D, Lindley CM (1997) Proposal for classifying the acute emetogenicity of cancer chemotherapy. J Clin Oncol 15:103-109

12. Nygren P, Hande K, Petty KJ, Fedgchin M, van Dyck K, Majumdar A, Panebianco D, de Smet M, Ahmed T, Murphy MG, Gottesdiener KM, Cocquyt V, van Belle S (2005) Lack of effect of aprepitant on the pharmacokinetics of docetaxel in cancer patients. Cancer Chemother Pharmacol 55:609-616

13. Sanchez RI, Wang RW, Newton DJ, Bakhtiar R, Lu P, Chiu SH, Evans DC, Huskey SE (2004) Cytochrome P450 3A4 is the major enzyme involved in the metabolism of the substance $\mathrm{P}$ receptor antagonist aprepitant. Drug Metab Dispos 32:1287-1292

14. Majumdar AK, Howard L, Goldberg MR, Hickey L, Constanzer M, Rothenberg PL, Crumley TM, Panebianco D, Bradstreet TE, Bergman AJ, Waldman SA, Greenberg HE, Butler K, Knops A, De Lepeleire I, Michiels N, Petty KJ (2006) Pharmacokinetics of 
aprepitant after single and multiple oral doses in healthy volunteers. J Clin Pharmacol 46:291-300

15. Chawla SP, Grunberg SM, Gralla RJ, Hesketh PJ, Rittenberg C, Elmer ME, Schmidt C, Taylor A, Carides AD, Evans JK, Horgan KJ (2003) Establishing the dose of the oral NK1 antagonist aprepitant for the prevention of chemotherapy-induced nausea and vomiting. Cancer 97:2290-2300

16. Heitz P, Polak JM, Timson DM, Pearse AG (1976) Enterochromaffin cells as the endocrine source of gastrointestinal substance P. Histochemistry 49:343-347
17. Freed AL, Audus KL, Lunte SM (2001) Investigation of substance $\mathrm{P}$ transport across the blood-brain barrier. Peptides 23:157-165

18. Higa GM, Auber ML, Altaha R, Piktel D, Kurian S, Hobbs G, Landreth K (2006) 5-Hydroxyindoleacetic acid and substance P profiles in patients receiving emetogenic chemotherapy. J Oncol Pharm Pract 12:201-209 